\title{
PAULO FREIRE'S SPIRIT HAS GUIDED MY WORK: CONFESSIONS OF THE FINNISH WORKING-CLASS ACADEMIC
}

DOI: $10.48075 /$ ri.v23i1.26706

Juha Suoranta ${ }^{1}$

ABSTRACT: Brazilian Paulo Freire is undoubtedly one of the most esteemed educational thinkers of the 20th century. Nevertheless, in Finland, my home country, Freire's influence on educational research and policy has been relatively marginal. However, from a micro-historical perspective, Paulo Freire's spirit has guided my and others' academic work on the margins of the educational and social sciences in Finland. I this article, I ponder Freire's influence on my scientific career and assess his general impact on the Finnish educational and social sciences.

\section{O ESPÍRITO DE PAULO FREIRE TEM ORIENTADO MEU TRABALHO: CONFISSÕES DO ACADÊMICO FINLANDÊS DA CLASSE TRABALHADORA}

RESUMO: O brasileiro Paulo Freire é sem dúvida um dos pensadores educacionais mais conceituados do século XX. No entanto, na Finlândia, meu país natal, a influência de Freire na pesquisa e nas políticas educacionais tem sido relativamente marginal. No entanto, desde uma perspectiva microhistórica, o espírito de Paulo Freire tem guiado o meu trabalho acadêmico e de outros, nas margens das ciências sociais e educacionais na Finlândia. Neste artigo, reflito sobre a influência de Freire em minha carreira científica e avalio seu impacto geral nas ciências sociais e educacionais finlandesas.

Key words: Pedagogia Crítica, Finlândia, Paulo Freire, Peter McLaren, Revolução.

\section{INTRODUCTION}

Brazilian Paulo Freire is undoubtedly one of the most esteemed educational thinkers of the 20th century. Freire's famous book, Pedagogy of the Oppressed, published in 1968, is

\footnotetext{
${ }^{1}$ Professor of Adult Education at Tampere University, Finland. He has published in sociology of education, public sociology, and critical pedagogy, and worked as Visiting Scholar at the University of Illinois at UrbanaChampaign in the 1990s and as Visiting Professor at the University of Minnesota in 2005-2006. His latest books are Artistic Research Methodology (2014), Rebellious Research (2014, in Finnish), C. Wright Mills's Sociological Life (2017, in Finnish), and Paulo Freire, A Pedagogue of the Oppressed (2019, in Finnish). juha.suoranta@tuni.fi
} 
the third most cited book in the social sciences, after Thomas Kuhn's The Structure of Scientific Revolutions and Everett Rogers's Diffusion of Innovations (see GREEN, 2016). Nevertheless, in Finland, my home country, Freire's influence on educational research and policy has been relatively marginal. Instead, as Suoranta and Tomperi (2020) point out:

El legado de Freire ha formado parte de una corriente alternativa de pensamiento educativo en Finlandia, aunque nunca fue explícitamente parte de las corrientes más ampliamente aceptadas. Lo mismo aplica en el caso de la política educativa finlandesa. El pensamiento freireano ha tenido relativamente poco efecto en este ámbito. (SUORANTA \& TOMPERI, 2020.)

Freire's invisibility in Finland is understandable when one compares the history of Brazil and Finland. As Suoranta and Tomperi further note:

No podemos dejar de resaltar que el proceso parlamentario vivido en Finlandia (...) en los años ' 60 , difiere mucho del contexto político que se vivía en Brasil durante el tiempo de Freire. En Brasil, el gobierno progresista había sido derrocado en un golpe de Estado en 1964, luego de que la clase dominante y de élite (clase elitista económica, políticos de derecha y grandes empresarios) haya decidido poner freno al desarrollo del activismo político y la educación en las clases populares. Tal como lo dice el propio Freire (2002), las élites poderosas pensaron que las clases populares y los pobres no eran parte de la democracia y no podían "participar activamente en el proceso histórico". En los países nórdicos el contexto político era diferente: las reformas educativas y de cualquier otro tipo, se daban en base a debates políticos democráticos. (SUORANTA \& TOMPERI, 2020.)

\section{FREIRE WAS DYNAMITE}

However, from a micro-historical perspective, the situation is quite different: Paulo Freire's spirit has guided my own and others' academic work on the margins of the educational and social sciences in Finland. I first encountered Paulo Freire's thinking in a social psychology textbook in the late 1980s. The author explained Freire's Marxist viewpoint. Freire defines a human being "as a subject who, through his activity, develops culture and history" (ESKOLA, 1982, p. 173). A few years later, I read Freire's book Pedagogy of the Oppressed ${ }^{2}$.

\footnotetext{
${ }^{2}$ I now have several copies of this work on my bookshelf; in my travels, I have often purchased Freire's book in different languages and editions.
} 
In his Education for Critical Consciousness (Educação como prática da Liberdade, 1967), Freire describes the broad division between oppressors and the oppressed in Brazil of the 1950s. Naturally, he positioned himself on the side of the oppressed (FREIRE, 2002; see also PEREIRA, 2019). In Pedagogy of the Oppressed, he presents a theory of how the oppressed can become aware of a repressive society's features and free themselves from their oppressors, thereby also liberating their oppressors at the same time. He argues that personal, social, and political liberation, a political and social act, begins with the teaching of literacy in cultural circles (FREIRE, 2005a.)

In these circles, the oppressed people gain political consciousness (conscientização) and come to understand their repressed position. They then become aware of their class status and join together as a new political force, thus becoming a class for themselves, in Marx's words. Together with revolutionary leaders, they can free themselves from social and economic domination and carry out their great humanistic and historical task of building a humane world rooted in the fundamental equality of all people.

The pedagogy of the oppressed, which is the pedagogy of people engaged in the fight for their own liberation, has its roots here. And those who recognize, or begin to recognize, themselves as oppressed must be among the developers of this pedagogy. No pedagogy which is truly liberating can remain distant from the oppressed by treating them as unfortunates and by presenting for their emulation models from among the oppressors. The oppressed must be their own example in the struggle for their redemption. (FREIRE, 2005a, p. 53-54) ${ }^{3}$.

These words were dynamite to students like me who had grown up in a working-class home in the progressive 1970s (see SUORANTA, 2015). The book became my "comrade," as it is even to this day. Freire provided me with a new direction; his ideas exploded the dirt of conservative, bourgeois educational sciences out of my head. The idea of the oppressed as a force for political revolution taught me that education and the educational sciences are profoundly political phenomena. This realization was a turning point, after which I could not continue in the mainstream social sciences.

\footnotetext{
3 In Portuguese: "A pedagogia do oprimido que, no fundo, é a pedagogia dos homens empenhando-se na luta por sua libertação, tem suas raízes aí. E tem que ter, nos próprios oprimidos que se saibam ou comecem criticamente a saber-se oprimidos, um dos seus sujeitos. Nenhuma pedagogia realmente libertadora pode ficar distante dos oprimidos, quer dizer, pode fazer deles seres desditados, objetos de um "tratamento" humanitarista, para tentar, através de exemplos retirados de entre os opressores, modelos para a sua "promoção". Os oprimidos hão de ser o exemplo para si mesmos, na luta por sua redenção."
} 
Freire was a free spirit of the revolutionary 1960s when he wrote Pedagogy of the Oppressed. The book cannot be pigeonholed into any specific discipline, for it is written primarily for the poor and marginalized and those who work alongside them. Freire did not want to classify his work; on one occasion, he said that "I didn't invent a method, or a theory, or a program, or a system, or a pedagogy, or a philosophy" (TORRES, Rosa 1997, p. 2).

Be as it may, Pedagogy of the Oppressed established a global tradition of critical research in education and a radically political educational movement. Educational theorists Michael Peters and Tina Besley $(2015$, p. 3) have compared Freire's global legacy to that of Nelson Mandela: Both were "motivated by many of the same political resources; elevated by similar political ideas of freedom, equality, and emancipation; and shaped by the same decades of radical activity during the 1960 s and 1970s."

The global tradition of critical research stemming from Freire includes, among others, the following topics: literacy and language, class division and class struggle, teaching practices and critical research methods, power and poverty, race and racism, culture and art, and activism and social movements (see APPLE; AU; GANDIN, 2009; DARDER, 2018; DARDER; BALTODANO; TORRES, R., 2003; KIRYLO, 2020; MCLAREN \& KINCHELOE, 2007; PETERS \& BESLEY, 2015; STEINBERG \& CANNELLA, 2012; STEINBERG \& DOWN, 2020, Section 1; TORRES, C. 2019). In general, Freirian critical pedagogy has promoted human rights and democratic socialism since the 1970s.

In these decades, Freirian scholars emphasized that "educational inquiry, as well as pedagogy as social practice, must be rethought from the standpoint of those who exist at the bottom of the global capitalist hierarchy if we are to prevail in the continuing war over scarce resources" (MCLAREN 2015, p. 25). Freire's book has brought tens of thousands of people together and created rich social and educational connections worldwide. I think of these networks as the global Freire University. When I think of Freire and the people his words and deeds have touched, I feel that I am one of them, even as I write this text in my home in Finland during the global COVID-19 pandemic.

\section{READING FREIRE IN HAVANA}


In 1999, I invited Professor Peter McLaren of UCLA (USA) to lecture in Finland. He had known Freire personally and had just finished writing his book on the revolutionary pedagogy of Paulo Freire and Ernesto "Che" Guevara (MCLAREN, 2000). Two of my students translated the book into Finnish ten years later (MCLAREN, 2009). Peter and I visited several Finnish universities during the tour and decided to meet again at the upcoming conference Marxism Today: A Renewed Left View in Havana, Cuba.

Thus, three months later, in February 2000, we met in the Hotel Habana Libre in Havana. Peter's book, Che Guevara, Paulo Freire, and the Pedagogy of the Revolution was fresh from the press, and as he entered my hotel room, he handed me the book. I read it enthusiastically late into the night and underlined the following paragraphs:

Paulo Freire was one of the first internationally recognized educational thinkers who fully appreciated the relationship among education, politics, imperialism, and liberation. In fact, he clearly understood that they unavoidably abut to one another as well as flash off each other. He was also acutely aware that under the name of the 'free market,' democracy had retracted its commitment to social justice, and along with that retraction had imperiled its fundamental commitment to education. (...) As Freire so compellingly proclaimed in his sui generis monumental tome, Pedagogy of the Oppressed, more and more of the world's peoples are no longer feasting at the grand banquet of capitalism; they are spending ever more of their time under the table groveling and scrounging with the dogs, searching for scraps at the feet of the ruling elite. According to Freire, the capitalist social structure cannot be ignored when attempting to fathom the complex interplay among meaning making, history making, and the process of becoming literate. Throughout the process of becoming literate-a conjunctural process that Freire referred to as 'praxis'-meaning circulates, is acted upon, and is revised, resulting in political interpretation, sense making, and will formation. (MCLAREN, 2000, p. 141, 149.)

The Havana conference was held at the Instituto Superior de Arte campus. A rumor circulated that Fidel Castro would show up at the meeting, but he did not. I cannot recall many of the talks now. Still, I do remember that the Cuban scholars, unlike most visiting colleagues, read their papers, which seemed to cite Marx's ideas almost word for word, without offering new or innovative leftist views, as the conference title promised. During the lunch and coffee breaks, a precious-looking waiter served the finest Cuban rum with local tuKola from metal carts that resembled a pathologist's table. In a photo taken outside the Arts Institute, I see myself smiling as I stand with the two prominent sociologists and cultural 
theorists Andrew Ross and Imre Szeman, who, among other curious academics from the capitalist world, had found their way to legendary Cuba.

I remember telling Andrew and Imre how vital an example Cuba was to Freire. The Cuban socialist revolution at the end of the 1950s inspired him, demonstrating to Freire that, for the most part, "education does not shape society, but society shapes education according to the interests of those who have power" (FREIRE, 1975, p. 24). The socialist revolution increased his hope that perhaps one day, in Brazil and elsewhere in Latin America, it would be possible to carry out a similar political and social change and create a society free from capitalist exploitation. Freire was also passionate about the Cuban literacy campaign of 1961 and was "moved by the Cuban accomplishment of making literate over 900,000 people in less than one year" (DE AGUIAR AMORIM et al., 2007; see also KOZOL, 1978).

The example of Cuba showed Freire that the feudal, capitalist social systems of Latin America were outdated. Those living in poverty could not develop their full potential as individuals in such conditions. For decades, centuries even, people had been forcibly coerced into serfdom's brutal regime and reassured by propaganda and ruthless violence that there was no alternative. No wonder Freire became interested in socialist Cuba. At the end of Pedagogy of the Oppressed, he considers how his literacy method, in which "reading the world always precedes reading the word, and reading the word implies continually reading the world" (FREIRE, 1983, p. 19), could enhance the socialist revolution. He adds that the socialist revolution materializes in the liberation of education to benefit all people.

Even more than the conference, I remember the warm Havanan nights. On one of those nights, a local family invited us to their home. The family's grandfather had fought in Sierra Maestra and served as a physician in Che's unit. Peter had some medicine and a pair of shoes he had brought with him from the physician's old U.S. friend. The friendly comrade showed us photos of himself standing beside Che in the mountains and of the victory parade in Havana's streets.

Another night we had dinner in one of the city's paladares, a mom-and-pop restaurant run by an ordinary Havanan family. They served us lean chicken legs with Moros y Cristianos in their tiny apartment, a Cuban version of rice and beans, while their boys watched the NBA on a black-and-white television in the next room. The broadcast was barely visible. As we left the paladar and stepped into the Malecón, we came across an LGBTQ person who told us about the mistreatment and open bigotry they experienced. They 
were delighted to walk with us; in our presence, the soldiers that seemed to be on every street corner refrained from throwing insults at them.

I started my days with a walk around the Havanan neighborhoods. One morning, I dared to enter the front gate of a nearby school. An old lady in a white coat welcomed me at the front door. I tried to explain in my practically non-existent Spanish (only a few words) that I was a professor of education from Finland, and I would like to visit her school. In perfect English, she replied that perhaps we could speak English instead. We chatted for quite a while, and she told me she had studied medicine in Chicago in the 1950s, before the socialist revolution. I learned that there is a school physician like her in every school in Cuba.

\section{BRINGING FREIRIAN INFLUENCES TO FINLAND}

As said, Freire's influence on mainstream Finnish educational sciences has been relatively small. An exception is Aino Hannula, who defended her pioneering dissertation on Paulo Freire in 2000, and I was lucky to be her opponent. A year later, I had the privilege of co-editing a book on critical pedagogy with Professor Tapio Aittola, a renowned sociologist of education (GIROUX \& MCLAREN, 2001).

The Finnish translation of Freire' Pedagogy of the Oppressed was a long time coming, but it was finally published in 2005 (FREIRE, 2005b). I had the privilege to write an afterword to the Finnish edition with a colleague: philosopher Tuukka Tomperi, who played a vital role in the translation process. Finnish students in the educational sciences are, if not familiar with his work, at least aware of Freire's thinking due to this translation. Today, other books, thesis, and translations discussing Freire's ideas are available in Finnish as well (e.g., HOOKS, 2007; KIILAKOSKI; TOMPERI; VUORIKOSKI, 2005; KURKI, 2002; MOISIO, 2009; NIVALA \& RYYNÄNEN, 2019; SUORANTA, 2005; SUORANTA, 2019; SUORANTA \& RYYNÄNEN, 2014).

In 2006, I edited a special issue of the Finnish Journal of Education dedicated to critical pedagogy. Freire's ideas were central to many of the articles. When I submitted the thematic issue, I was working as a visiting professor in the Department of Sociology at the University of Minnesota in the U.S.; I encountered Freire's influence there as well. Sociologist Michael Burawoy mentioned Freire in his lecture on public sociology. In the spirit of Freire, he stressed that teaching sociology is, at its best, a series of dialogues "between ourselves and students, between students and their own experiences, among students 
themselves, and finally a dialogue of students with publics beyond the university" (BURAWOY, 2005, p. 9, see also BURAWOY \& VON HOLDT, 2012, chapter 5).

I became interested in public sociology during my stay in Minnesota, and I have taught it to social science students at Tampere University nearly every year since 2009, except for some intermediate years. In the spring of 2019, our course's preliminary reading was Pedagogy of the Oppressed. In my view, public sociology is to sociology what Freire's thinking is to educational sciences. That is to say, both shed light on the social and political plagues of capitalism, class war, racism, bigotry, domination, hegemony, and ideological distortion.

Over the years, several Freire centers have emerged around the world; some of them operate in conjunction with universities. Since there was no such center in the Nordic countries, I decided to establish one in 2007 (https://paulofreirefinland.wordpress.com/). Peter McLaren gave the center's inaugural lecture on "Paulo Freire and Critical Pedagogy in the Times of Neoliberal Terror."

Over the next two summers, in 2008 and 2009, Peter and I organized Critical Pedagogy Summer Schools with my colleagues Tapio Aittola and Olli-Pekka Moisio. Peter McLaren taught at the school for both years. The summer school drew participants from Ph.D. students at different Finnish universities, and we edited three volumes on critical pedagogy drawn from the summer school presentations (AITTOLA; ESKOLA; SUORANTA, 2007; LANAS; NIINISTÖ; SUORANTA, 2008; MOISIO \& SUORANTA, 2009). Now, near the end of October 2020, those books have been downloaded over 20,000 times as e-books.

During the late 2000s and early 2010s, I was active in the Annual Conferences of Finnish Educational Research, along with Tapio Aittola, who had introduced Freire and critical pedagogy in his teaching already in the 1990s. We organized a Critical Pedagogy Special Interest Group at several conferences; of those, one meeting in Vaasa in 2007 was among the most memorable.

Peter McLaren gave the conference's keynote, and a group of students from the University of Art and Design had decided to make a field trip to listen to his lecture and meet him. They had read my book Radikaali kasvatus ('Radical Education,' 2005), an introduction to the critical education tradition, and been inspired to study radical figures such as Freire, Marx, and McLaren, along with other critical thinkers. At the conference, they met Peter in person; later, we met again at the local bar. One of the art students was Lissu Lehtimaja, 
who had drawn a documentary comic on Freire as her artistic theses (LEHTIMAJA, 2006). The multitalented Lissu Lehtimaja was also the lead singer in the band Maria Gasolina (active 2001-2019), which played primarily Brazilian pop music with Finnish lyrics (https://www.mariagasolina.net/).

\section{A BOOK ON FREIRE}

Paulo Freire's words have given me comfort and encouragement when I have needed them most. In the late 2000s, I helped an underage asylum seeker at risk of deportation stay in Finland (see SUORANTA, 2021). In difficult moments, I thought of Freire's experiences in exile and his words that "the pursuit of full humanity cannot be carried out in isolation or individualism, but only in fellowship and solidarity" (FREIRE, 2000, p. 85). These words gave me the courage to believe that, because the world is not fair, it is essential to help people in difficult situations (SUORANTA, 2010, p. 67).

I had taught Freire in my teaching for many years, but did I know who he was? What were his roots; what was the sociopolitical context of his work? In 2017, when the Democratic Civic Association (DCA) invited me to speak about Freire's and Marx's relationship during their summer seminar at the Vähäjärvi holiday home in Lautsia, Finland, I had to start rereading Freire, and - as you know - rereading always generates something new.

The DCA is a leftist non-governmental organization in Finland. It focuses on the leftist and working-class movements' educational objectives. Its main principles are "global solidarity, social and economic justice, and the ideas of peace, humanism, and socialism" (DEMOCRATIC CIVIC ASSOCIATION). The organization "supports people's actions in the civic and cultural fields and especially those in leftist and workers' organizations, and labor, peace, environmental, and other civil movements. The DCA promotes contemporary Marxist studies and publishes literature and material for study and discussion." The organization's most important member is the Communist Party of Finland. (DEMOCRATIC CIVIC ASSOCIATION.)

After the event, the DCA's head of department asked if I had thought about writing a book on Freire. It would, he said, be urgently needed. Encouraged by his words, I promised to try. When I was drafting the book, I realized that I did not know much about Freire's 
development as a revolutionary educator. The book for the Finnish audience was born out of this very question (see SUORANTA, 2019). At the end of the book, I list some recommendations in Freire's spirit for those who want to use his ideas in their research and practices. These are my nine suggestions:

- Social reality is an entity "in the making" and "the result of the practice of human beings on reality" (FREIRE, 1975, p. 14, italics in original); it is not a realm of necessity, but of freedom. Social reality consists of different relationships, one of which is the relationship between the oppressed and the oppressors. As Freire reminds us, it is the task of the oppressed, not only to free themselves from the oppressors but also to free their oppressors (FREIRE, 2005a).

- The historical and cultural world is a human creation, and thus, humans can change it. The world is not a static entity; in the words of Friedrich Engels (1886, para. 5, italics in original), "the world is not to be comprehended as a complex of readymade things, but as a complex of processes, in which the things apparently stable, no less than their mind images in our heads, the concepts, go through an uninterrupted change of coming into being and passing away, in which, in spite of all seeming accidentally and of all temporary retrogression, a progressive development asserts itself in the end."

- It is crucial to shed light on those social relations, policies, and institutional bureaucratic practices that reproduce oppression and powerlessness and threaten to destroy the entire planet and its habitats. People need to explore alternative ways of being and living. They should be active in social movements that defend democracy, human rights, and the struggle against right-wing authoritarianism and populist totalitarianism. Thus, they realize that an "otro mundo es possible."

- $\quad$ Social activism helps us understand the connections between our own lived lives and other people and the construction of circumstances and history. In this way, we can also grasp the connections between our biographies and history and turn private problems into social issues.

- $\quad$ These societal issues give rise to mass movements and political projects that spread participants' ideas, develop new ideas, and propose solutions to societal problems. The oppressed become the gravediggers of capitalism, uniting as a force to overthrow the destructive social system. 
- In Freirian dialogical processes, participants understand what it means to be a genuine human actor. Their actions relate to their experiences and needs, not to those the ruling elite presents to them.

- In this way, people learn the ideological myths and outright lies that govern and oppress them. They become critically aware of how the ruling elite uses and abuses power, especially in conjunction with economic and military power, in ways that threaten not only individual human development but also the planet's future.

- $\quad$ Critical Freirian researchers must learn, among other things, to be political agents. Thus, they can use their theoretical knowledge and research skills in action to outline the possibilities of a different world. They can observe, gather information, discuss, write, and publish. They can, most of all, participate in negotiation processes and collectively work to transform and rewrite the world critically. Researchers and the people need each other, and they must join forces!

- According to Freire, people must abolish capitalism, stop inhumane economic forces, and reverse destructive technological development: "The future belongs to the Peoples and not to the Empires" (FREIRE, 2004, p. 56).

\section{CONCLUSION}

In the next years, I plan to follow Comrade Freire's path to Europe and walk with him to the World Council of Churches' headquarters in Geneva, where he worked for ten years, from 1970 to 1980. My next book's working title is Pilgrim of the Obvious: Freire's Journey to World Fame. Why this title? The World Council of Churches organized a seminar on September 6, 1974, in Geneva, Switzerland, entitled An Invitation to Conscientization and Deschooling: A Continuing Conversation. At this event, the educational ideas of Freire and Ivan Illich (1926-2002), a social and educational antagonist, were discussed. Both of them were present.

In his speech at the conference, Freire called himself a "pilgrim of the obvious," explaining, "In this pilgrimage, I am learning how important it is to take the obvious as an object for critical reflection and, going into it more deeply, I find that it is not, at times, as obvious as it seems" (FREIRE, 1975, p. 17). He added that, in this mission, he must speak and write about those things and issues of concern - obviousnesses - that people already know and may even discuss in private but may not have expressed or brought to light. 
Freire's task is still relevant today, perhaps more relevant than ever. It is urgent that we reflect and critically act upon the obviousnesses of our time: climate change, the widening gap between rich and poor, right-wing populism, neofascism, and the arms race.

\section{REFERENCES}

AITTOLA, T., ESKOLA, J. \& SUORANTA, J. (Eds.). Kriittisen pedagogiikan kysymyksiä ('Questions of Critical Pedagogy'). Tampere: University of Tampere, 2007. http://urn.fi/urn:isbn:978-951-44-7166-7

APPLE, M., AU, W. \& GANDIN, A. (Eds.). The Routledge International Handbook of Critical Education. New York \& London: Routledge, 2009.

DARDER, A., BALTODANO, M. \& TORRES, R. The Critical Pedagogy Reader. New York \& London: RoutledgeFalmer, 2003.

DE AGUIAR AMORIM, M., PEREZ CRUZ, F., CONTRERAS, R. HOLST, J., VETTER, M. \& BAHRUTH, R. (2007). 40 Years from Education as the Practice of Freedom: New Perspectives on Paulo Freire from Latin America. Adult Education Research Conference Paper 4, 2007. http://newprairiepress.org/aerc/2007/symposia/4

DEMOCRATIC CIVIC ASSOCIATION http://www.desili.fi/in-english/ Accessed October 13, 2020.

ESKOLA, A. Vuorovaikutus, muutos, merkitys. ('Interaction, Change and Meaning'). Helsinki: Tammi, 1982.

ENGELS, F. Ludwig Feuerbach and the End of Classical German Philosophy, 1886. https://www.marxists.org/archive/marx/works/1886/ludwig-feuerbach/ch04.htm Accessed October 7, 2020.

FREIRE, P. Pilgrims of the Obvious. Risk 11(1), 1975, p. 13-18.

FREIRE, P. The Importance of the Act of Reading. Journal of Education 165(1), 1983, p. 5-11.

FREIRE, P. Education for Critical Consciousness. New York: Continuum, 2002.

FREIRE, P. Pedagogy of Indignation. Boulder: Paradigm Publishers, 2004.

FREIRE, P. Pedagogy of the Oppressed. 30th Anniversary Edition. New York: Continuum, 2005a. 
FREIRE, P. Sorrettujen pedagogiikka ('Pedagogy of the Oppressed'). Transl. Joel Kuortti. Tampere: Vastapaino, 2005b.

BURAWOY, M. For Public Sociology. American Sociological Review 70, 2005, p. 4-28.

BURAWOY, M. \& VON HOLDT, K. Conversations with Bourdieu: The Johannesburg Moment, 2012. http://burawoy.berkeley.edu/Books/Bourdieu.SA/Conversation\%205.pdf

DARDER, A. The Student Guide to Freire's Pedagogy of the Oppressed. London: Bloomsbury Academic, 2018.

GIROUX, H. \& MCLAREN, P. Kriittinen pedagogiikka ('Critical Pedagogy'). Transl. Jyrki Vainonen. Tampere: Vastapaino, 2001.

GREEN, E. What are the most-cited publications in the social sciences (according to Google Scholar), 2016. https://blogs.Ise.ac.uk/impactofsocialsciences/2016/05/12/what-are-themost-cited-publications-in-the-social-sciences-according-to-google-scholar (3.1.2020)

HANNULA, A. Tiedostaminen ja muutos Paulo Freiren ajattelussa. Systemaattinen analyysi Sorrettujen pedagogiikasta. ('Conscientization and Change in Paulo Freire's Thinking. A systematic analysis of Pedagogy of the Oppressed'). University of Helsinki: Faculty of Education, 2000. http://urn.fi/URN:ISBN:951-45-9420-7

HOOKS, B. Vapauttava kasvatus ('Teaching to Transgress. Education as the Practice of Freedom'). Helsinki: Kansanvalitusseura, 2007.

KIRYLO, J. Reinventing Pedagogy of the Oppressed. The Enduring Legacy of Paulo Freire. London: Bloomsbury Academic, 2020.

KIILAKOSKI, T., TOMPERI, T. \& VUORIKOSKI, M. (Eds.). Kenen kasvatus ('Whose Education'). Tampere: Vastapaino, 2005.

KOZOL, J. A New Look at the Literacy Campaign in Cuba. Harvard Educational Review 48(3), 1978, p. 341-377.

KURKI, L. Persoona ja yhteisö ('Person and Community’). Jyväskylä: SoPhi, 2002.

LANAS, M., NIINISTÖ, H. \& SUORANTA, J. (Eds.). Kriittisen pedagogiikan kysymyksiä 2 ('Questions of Critical Pedagogy 2'). Tampere: Tampereen yliopisto, 2008. http://urn.fi/urn:isbn:978-951-44-7544-3

LEHTIMAJA, L. Freiren kyydissä ('Riding with Freire'). Helsinki: Like, 2006.

MCLAREN, P. Che Guevara, Paulo Freire, and the Pedagogy of the Revolution. Lanham: Rowman \& Littlefield, 2000. 
MCLAREN, P. Che, Freire ja vallankumouksen pedagogiikka ('Che Guevara, Paulo Freire, and the Pedagogy of the Revolution'). Transl. T. Ahponen and L. Poser. Helsinki: Like, 2009.

MCLAREN, P. Reflections on Paulo Freire, Critical Pedagogy, and the Current Crisis of Capitalism. In: PETERS, M. \& BESLEY, T. (Eds.). Paulo Freire. The Global Legacy. New York: Peter Lang, 2015, p. 17-37.

MCLAREN, L. \& KINCHELOE, J. (Eds.). Critical Pedagogy. Where Are We Now? New York: Peter Lang, 2007.

MOISIO, O-P. Essays on Radical Educational Philosophy. Jyväskylä: University of Jyväskylä, 2009.https://www.researchgate.net/publication/304019730 Essays on Radical Educationa I Philosophy

MOISIO, O-P. \& SUORANTA, J. (Eds.). Kriittisen pedagogiikan kysymyksiä 3 ('Questions of Critical Pedagogy 3'). Tampere: Tampereen yliopisto, 2009. http://urn.fi/urn:isbn:978-95144-7900-7

NIVALA, E. \& RYYNÄNEN, S. Sosiaalipedagogiikka ('Social Pedagogy') Helsinki: Gaudeamus, 2019.

PEREIRA, S. Educação como Prática da Liberdade. Educação \& Linguagem 22(2), 2019, p. 211-216.

https://www.metodista.br/revistas/revistasmetodista/index.php/EL/article/view/9937/7090

PETERS, M. \& BESLEY, T. (toim.). Paulo Freire. The Global Legacy. New York: Peter Lang, 2015.

RYYNÄNEN, S. Nuoria reunoilla. Sosiaalipedagoginen tutkimus rikollisuuden ja väkivallan keskellä elävien nuorten kasvun tukemisesta brasilialaisissa kansalaisjärjestöissä ('Young People on the Edge. Socio-pedagogical research on the pedagogical support provided by Brazilian NGOs for the growth of young people living in the context of crime and violence'). Acta Electronica Universitatis Tamperensis 1088, 2011. http://urn.fi/urn:isbn:978-951-44$\underline{8482-7}$

STEINBERG, S. \& CANNELLA, G. (Eds.). Critical Qualitative Research Reader. New York: Peter Lang, 2012.

STEINBERG, S. \& DOWN, B. (Eds.). The SAGE Handbook of Critical Pedagogies. Thousand Oaks: Sage, 2020.

SUORANTA, J. Radikaali kasvatus ('Radical Education') Helsinki: Gaudeamus, 2005.

SUORANTA, J. Hidden in Plain Sight. Transl. Silja Kudel. Helsinki: Into, 2010. https://www.researchgate.net/publication/272506252 Hidden in Plain Sight 
SUORANTA, J. Towards Rebellious Research: Pages from the Sketchbook of a Working-Class Academic. In: PORFILIO, B., \& FORD, D. (Eds.). Leaders in Critical Pedagogy: Narratives for Understanding and Solidarity. Rotterdam: Sense Publishers, 2015, p. 199-210.

SUORANTA, J. Paulo Freire. Sorrettujen pedagogi. ('Paulo Freire. A Pedagogue of the Oppressed'). Helsinki: Into, 2019.

SUORANTA, J. Ashraf, Paulo and Me, or Where Heterogeneous Realities Meet. In: KRESS, T., LAKE, B. \& STEIN, E. (Eds.) Radically Dreaming: Illuminating Freirean Praxis in Dark Times. DIO Press, 2021.

SUORANTA, J. \& RYYNÄNEN, S. Taisteleva tutkimus ('Rebellious Research'). Helsinki: Into, 2014.

SUORANTA, J. \& TOMPERI, T. Freire en Finlandia: trayectorias de la presencia de Paulo Freire en el Norte global. Archivos De Ciencias De La Educación 13(16), 2020. https://www.archivosdeciencias.fahce.unlp.edu.ar/article/view/Archivose069

TORRES, C. (ed.). The Wiley Handbook of Paulo Freire. London: Wiley-Blackwell, 2019.

TORRES, R. M. The Million Paulo Freires. Convergence 31, 1997, p. 1-2. https://www.dvvinternational.de/en/adult-education-and-development/editions/aed-692007/10thanniversary-of-paulo-freirersquos-death/the-million-paulo-freires

Recebido em 31 de agosto de 2020.

Aprovado em 03 de novembro de 2020

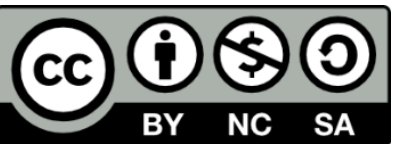

